\title{
Phytochemical Screening and Antibacterial Activity of Erythrina variegata L. (Leaf Extract)
}

\author{
Preeti Kumari*, Subhankar K. Singh and Chandrawati Kumari \\ Department of Biotechnology, A.N. College, Magadh University, Patna, Bihar, India \\ *Corresponding author
}

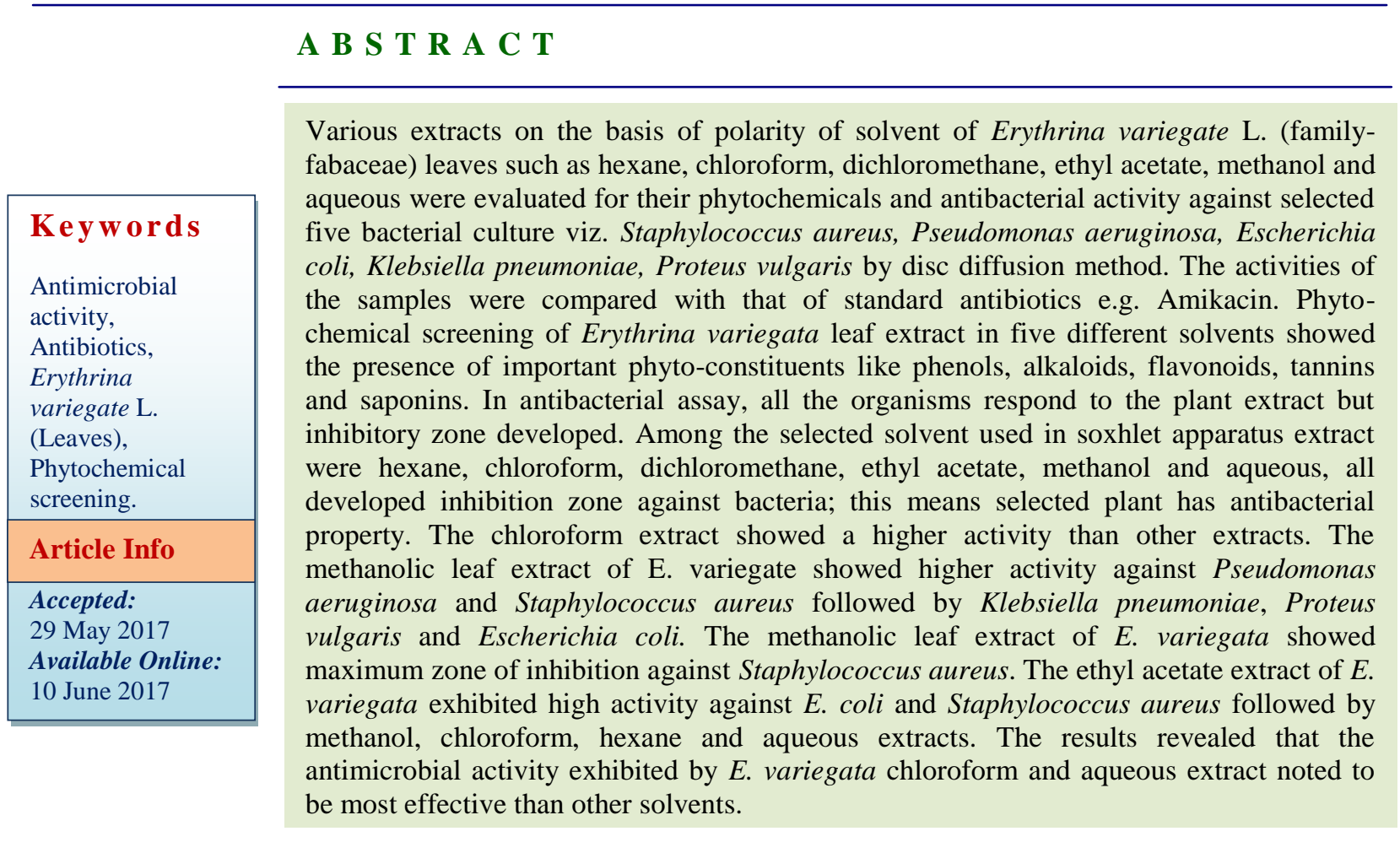

\section{Introduction}

Protective or disease preventive properties of phytochemicals are widely known and recognized. They are non-nutritive plant based chemical which are supposed to be nonessential for the human body. However, researches have proved that many phytochemicals can be highly useful in protecting humans against diseases. Even today, over $80 \%$ of the world population, especially in the developing world practices traditional medicine prepared from plant extract for their health and wellness (Viji, 2010). Natural plants are significantly important for their role in medicine and plant metabolites became major player in recent drug discovery and formulation. They are important source of noble drugs compounds which results in plant derived medicines (Cardero et al., 2012). It is well known that secondary metabolites are a source of 
biologically active natural products with various functions, including antibacterial, antifungal, antiviral, antineoplastic and anticancer activities, acting also as inhibitors and plant growth promoters (AL-Zereini, 2006). The major advantage offered by the use of these metabolites as useful templates, is that they are per se highly active and selective. They can also be used within the structure of its active sites, in order to develop new substances with predetermined properties (Gonzalez and Silva, 2001). In addition, chemical research related to the isolation, biosynthesis and structural elucidation of new natural compounds has contributed to pharmaceutical progress, for example, in treatment of diseases, pests and the development of new chemicals (AL-Zereini, 2006).

Plant of Erythrina variegata (Division: Magnoliophyta - Flowering plants, Class: Magnoliopsida - Dicotyledons, Family: Fabaceae (Legume family), Subfamily: Papilionoideae, Genus: Erythrina L. - Coral Tree, Species: E. variegata L.) is universally recognized for their high biomass productivity and utilization. This plant is reported to be a highly popular cultivated plant in India having deciduous tree shaped, upto $13 \mathrm{~m}$ tall; unarmed; bark yellowish or greenish grey, smooth; wood white; young branches pubescent, prickled, which fall when a few years old. Leaves 3-foliolate, rachis 20-30 $\mathrm{cm}$; petiole $15-20 \mathrm{~cm}$; leaflets thin coriaceous, ovate-rhomboid, $5-15 \times 5.5-17 \mathrm{~cm}$, glabrous, apex acuminate, margin entire, base truncate, obtuse; secondary nerves 5-6 pairs, petiolule to $8 \mathrm{~mm}$. Flowers scarlet, $2.5 \mathrm{~cm}$ across in 5$15 \mathrm{~cm}$ long, dense racemes. Pod torulose, 2035 x 2.5-3 cm, deep brown, stipulate; seeds 712, 1.5-1.8 cm long, dark purple (Pullaiah and Sandhaya Rani, 1999). Different parts of E.variegata have used in traditional medicine as nervine sedative, febrifuge, anti-asthmatic and antilepileptic. In some experiments, it has potential effects for treatment of some diseases like convulsion, fever, inflammation, bacterial infection, insomnia, helminthiasis, cough, cuts and wounds (Warrier et al., 1994, Gupta et al., 2002., Ghosal et al., 1972). We therefore undertook this study to evaluate the phytochemical constituents and antibacterial potential of the various solvent extracts, from the leaves of E. variegata (Muthukrishnana, 2014). However, few scientific and systematic studies have been done on phytochemical screening and isolation of secondary metabolites in E. variegata for their antibacterial efficacy. Considering international interest in herbal medicine research on this underutilized plant as a source of bioactive chemicals was carried out with the objective of evaluating its potential antibiotic activities to make a diagnosis of the chemistry related to the plant extract of E. variegata in order to explore new and noble bioactive compounds (Srinivasan, et al., 2001).

\section{Materials and Methods}

\section{Collection of plant sample}

The fresh leaves of E. variegata were collected from Agamkuan near RMRIMS, Patna randomly.

\section{Preparation of leaf extracts}

The leaves were washed thoroughly with tap water and in distilled water and then shaded dried the leaves at room temperature. The dried leaves were ground to a fine powder in a mechanic grinder. About 100gm of powdered plant material was uniformly packed into a thimble made up of muslin cloth and extracted with $500 \mathrm{ml}$ of different solvents separately in Soxhlet apparatus. Solvents used were hexane, chloroform, dichloromethane, ethyl acetate, methanol and aqueous on the basis of their polarity. The process of 
extraction continues till the solvent in tube of an extractor become colorless. The extracts were filtered through muslin cloth or Whatman No.1 filter paper and collected in brown bottle separately. After that the different extract solvent was evaporated by rota vapour separately, where the temperature of water bath should be at $40^{\circ} \mathrm{C}$, which gave rise to a solid mass of the extract. The solid mass was refrigerated for further use.

\section{Phytochemical analysis}

The qualitative analysis of tannins, phenols, glycosides, alkaloids, steroids and flavonoids were analyzed by standard method (Harborne, 1973).

\section{Selected test microorganisms}

Extracts were tested against pathogenic microbes, including the bacteria Pseudomonas aeruginosa, Escherichia coli, Proteus vulgaris, Staphylococcus aureus, and Klebsiella pneumoniae.

\section{Antibacterial assay}

Antibacterial activity of plant extracts was carried using agar disc diffusion method with some minor modifications. $(200 \mu \mathrm{l}$ bacterial cultures were spread in nutrient agar culture plate by glass rod spreader. Disc of $6 \mathrm{~mm}$ of plant different solvent extract along with positive control and negative control were diffused in the Petri plate and after incubation, zone of inhibition were read by mm scale (Murray, 2009).

\section{Results and Discussion}

\section{Phytochemical screening of Erythrina variegata}

Presence and absence of primary phytochemicals viz., alkaloids, flavonoids, glycosides, steroids, phenols, tannins, saponins and resins was confirmed in the laboratory tests.

Some plant extracts and phytochemicals are known to have antibacterial properties, which could be of great importance in the therapeutic treatments. The preliminary phytochemical results of selected solvent extracts of E. variegata were showed in the table 1. Phytochemical screening of aqueous leaf extract of $E$. variegata contained Glycosides, phenols and tannins. Methanolic extract revealed the presence of flavonoids, glycosides, phenols, tannins and resins. The ethylacetate extract showed the presence of alkaloids, flavonoids, phenols, tannins and resins.

The qualitative phytochemical analysis indicates that hexane extract possess flavonoids, glycosides and saponins. Dichloromethane extract were found to contain flavonoids, glycosides, phenols and tannins. From the phytochemical analysis it was noted that all the extracts of E. variegata leaf are rich in various secondary metabolites such as phenolics, alkaloids, flavonoids, tannins and saponins. Among the various solvents screened for phytochemicals, hexane, chloroform, dichloromethane, ethyl acetate, methanol and aqueous are very effective. It has been mentioned that antioxidant activity of plants might be due to their phenolic compounds (Cook et al., 1996). Flavonoids are most commonly known for their antioxidant activity. They are modifiers which modify the body's reactions to allergens, viruses, and carcinogens. They show antiallergic, anti-inflammatory, antimicrobial and anticancer activity (Balch, 2000).

The presence of alkaloids explains its antibacterial activity, since this phytochemical is reported to have anti-bacterial activity (Idowu et al., 2003). Tannins are reported to have various physiological effects like anti-irritant, antisecretolytic, antiphlogistic, antimicrobial 
and antiparasitic effects. Phytotherapeutically tannin-containing plants are used to treat nonspecific diarrhoea, inflammations of mouth and throat and slightly injured skins.

\section{Antibacterial activity of Erythrina variegata}

The antibacterial activity has been screened because of its great medicinal relevance with the recent years, infections have increased to a great extent and resistance against antibiotics, become an ever increasing therapeutic problem (Ali et al., 2001). Plant based antimicrobials have enormous therapeutic potential as they can serve the purpose without any side effects that are often associated with synthetic antimicrobial compounds. Some of the photo of experimental finding is given hereunder.

Table.1 Preliminary phytochemical screening of selected solvent leaf extracts of E. variegate

\begin{tabular}{|c|c|c|c|c|c|c|c|}
\hline S.No. & $\begin{array}{c}\text { Phyto- } \\
\text { chemicals }\end{array}$ & n-Hexane & Chloroform & dichloromethane & ethylacetate & methanol & aqueous \\
\hline 1. & Alkaloids & - & - & - & + & - & - \\
\hline 2. & Flavonoids & + & + & + & + & + & - \\
\hline 3. & Glycosides & + & + & + & - & + & + \\
\hline 4. & Steroids & - & - & - & - & - & - \\
\hline 5. & Phenols & - & + & + & + & + & + \\
\hline 6. & Tannins & - & + & + & + & + & + \\
\hline 7. & Saponins & + & - & - & - & - & - \\
\hline 8. & Resins & - & - & - & + & + & - \\
\hline
\end{tabular}

$+=$ Presence, - - Absence.

Table.2 Antibacterial activity of selected solvent extracts of Erythrina variegate $(10 \mathrm{mg} / \mathrm{ml})$

\begin{tabular}{|l|l|l|l|l|l|l|l|l|l|}
\hline S.No. & Bacterial strain & $\begin{array}{l}\mathrm{P}+ \\
\text { control }\end{array}$ & $\begin{array}{l}\mathrm{N}- \\
\text { control }\end{array}$ & $\begin{array}{l}\mathrm{N}- \\
\text { hex. }\end{array}$ & Chlof. & DCM & $\begin{array}{l}\text { Ethyl } \\
\text { acetate }\end{array}$ & Methanol & Aqueous \\
\hline 1. & E.coli & $30 \mathrm{~mm}$ & $7 \mathrm{~mm}$ & $12 \mathrm{~mm}$ & $11 \mathrm{~mm}$ & $8 \mathrm{~mm}$ & $13 \mathrm{~mm}$ & $10 \mathrm{~mm}$ & $20 \mathrm{~mm}$ \\
\hline 2. & $\begin{array}{l}\text { Pseudomonas } \\
\text { aeruginosa }\end{array}$ & $30 \mathrm{~mm}$ & $7 \mathrm{~mm}$ & $8 \mathrm{~mm}$ & $11 \mathrm{~mm}$ & $8 \mathrm{~mm}$ & $8 \mathrm{~mm}$ & $10 \mathrm{~mm}$ & $20 \mathrm{~mm}$ \\
\hline 3. & $\begin{array}{l}\text { Proteus } \\
\text { vulgaris }\end{array}$ & $30 \mathrm{~mm}$ & $7 \mathrm{~mm}$ & $8 \mathrm{~mm}$ & $12 \mathrm{~mm}$ & $8 \mathrm{~mm}$ & $10 \mathrm{~mm}$ & $10 \mathrm{~mm}$ & $8 \mathrm{~mm}$ \\
\hline 4. & $\begin{array}{l}\text { Staphylococcus } \\
\text { aureus }\end{array}$ & $30 \mathrm{~mm}$ & $7 \mathrm{~mm}$ & $12 \mathrm{~mm}$ & $10 \mathrm{~mm}$ & $11 \mathrm{~mm}$ & $13 \mathrm{~mm}$ & $11 \mathrm{~mm}$ & $8 \mathrm{~mm}$ \\
\hline 5. & $\begin{array}{l}\text { Klebsiella } \\
\text { pneumoniae }\end{array}$ & $28 \mathrm{~mm}$ & $7 \mathrm{~mm}$ & $13 \mathrm{~mm}$ & $11 \mathrm{~mm}$ & $10 \mathrm{~mm}$ & $8 \mathrm{~mm}$ & $11 \mathrm{~mm}$ & $9 \mathrm{~mm}$ \\
\hline
\end{tabular}

Note: $\mathrm{P}+$ positive control $=$ Amikacin $(10 \mu \mathrm{l})$ and $\mathrm{N}-$ negative control $=$ Sterilized Distilled water 
Fig.1 Antibacterial activity of Erythrina variegata
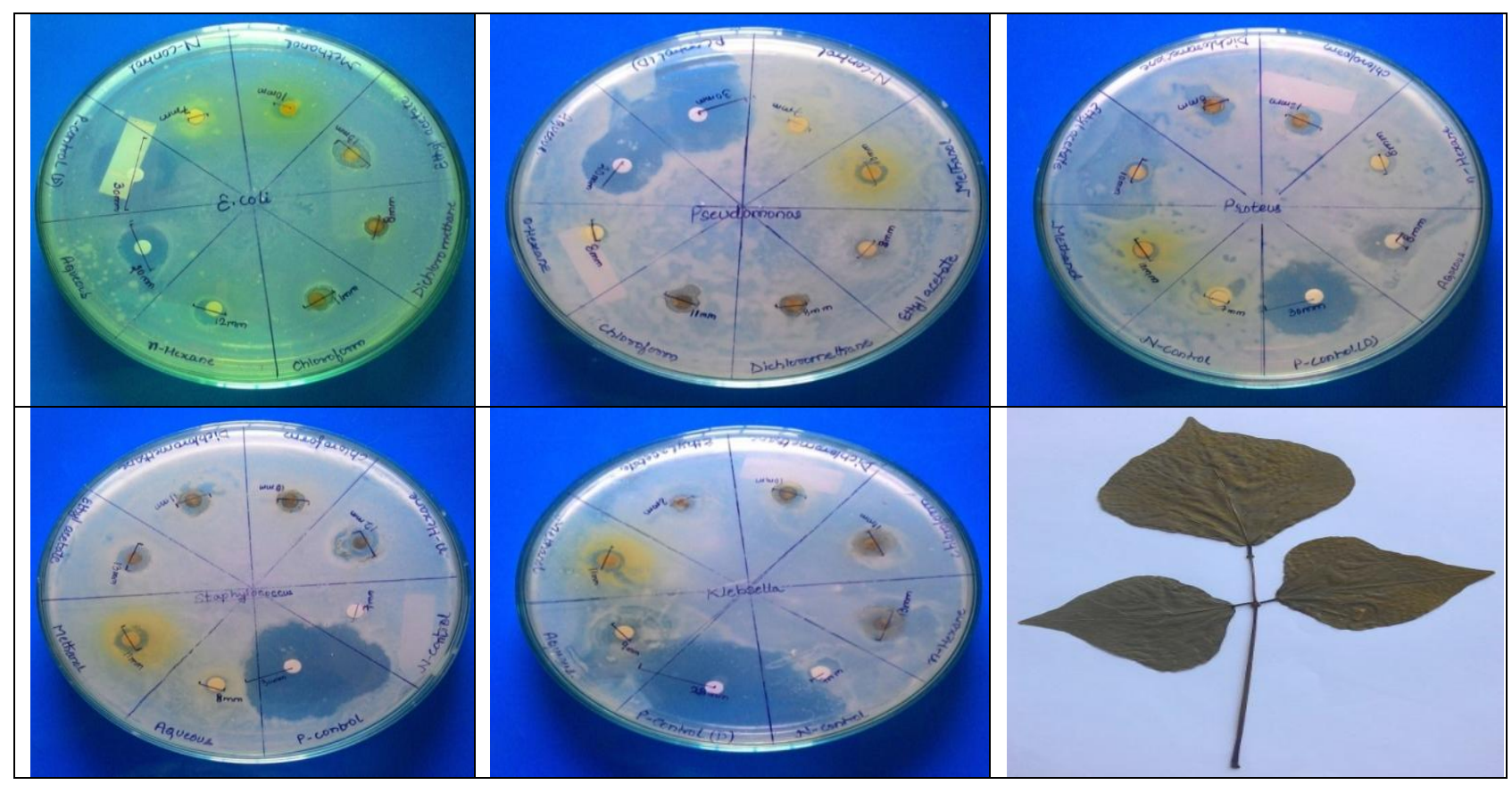

Table.2 represents the antibacterial effect of selected solvent extracts of Erythrina variegata by agar- disc diffusion method against selected bacterial strains and the zone of inhibition was assessed in millimeter diameter. The aqueous extract of plant showed best zone of inhibition against Escherichia coli and Pseudomonas aeruginosa. Methanolic extract showed significant activity against Escherichia coli and Pseudomonas aeruginosa and same zone of inhibition result against Proteus, Staphylococcus and Klebsiella (Haque et al., 2006). The ethylacetate and dichloromethane showed moderate zone of inhibition against bacteria. The antibacterial activity of n-hexane of Erythrina variegata showed maximum zone of inhibition against Klebsiella comparison to others. The chloroform showed constantly best zone of inhibition in all bacteria among all other solvents. The standard antibiotic "Amikacin" showed good antibacterial activity and it is considered as standard antibacterial drugs as used today which is taken as positive control against others bacterial strains (Fig. 1).

It is concluded that the antibacterial activity of crude extract from the leaves of E. variegata may be due to the presence of various phytochemical constituents indulged in them. Therefore the extracts of E. variegata could be recommended as a source of pharmaceutical and traditional drug materials required for preparation of antibacterial agents. This plant different solvents extract recommended further as best antibacterial drug. This study related to zone of inhibition of E. variegata extract seems that all the selected extract possess significant antibacterial activity against Gram positive and Gram - negative bacterial pathogens and this results seems to be interesting and notable. This may be due to the solvent extract containing different constituents having antibacterial activity.

\section{Acknowledgement}

The authors are thankful to Principal of A.N College, Patna and Director RMRIMS, Patna for providing me laboratory and library facility.

\section{References}

Ali, N.A.A., Julich, W.D., Kusnick, C., Lindequist, U., 2001.Antimicrobial and 
phytochemical studies on 45 Indian medicinal plants against multi-drug resistant human pathogens. Journal of Ethnopharmacology., 74, 113-123.

AL-Zereini,W., 2006. Natural products from marine bacteria. Ph.D Thesis, University of Kaiserslautern, Germany.

Balch, J.F and Balch, P.A., 2000.Prescription for Nutritional Healing. New York: A very, Penguin Putnam Inc.pp.267-270.

Cardero M., Borbon H., Roman R. Felix., Viquez R., Villegas R. Luis., et.al., 2012. Antimicrobial Activity and Phytochemical Screening of Secondary metabolites extracted From the Ascidian Rhopalaea Birkelandi, European Journal of Scientific Research, Vol. 70 No. 3, 345-353.

Cook, N.C and Samman, S., 1996. Flavonoidschemistry, metabolism, cardio protective effects, and dietary sources. Nutritional Biochemistry, 1996; 7: 66- 76.

Ghosal S, Dutta S.K, Bhathacharya S.K. Erythrina - chemical and pharmacological evaluation II: Alkaloids of Erythrina variegata L. J Pharm Sci., 1972; 61:1274- 7. [PubMed: 5050377].

Gonzalez, F., Silva, M., 2001. Biodiversidad Quimica de Macroalgas Marinas. In Sustentabilidad de la biodiversidad un problema actual bases cientificotecnicas, teorizaciones y proyeccines; Alveal. K., Antezana, T., Eds.; Universidad de Concepcion: Concepcion, Chile, pp 415-496.

Gupta V.K, editor. The Wealth of India (A dictionary of Indian raw materials and industrial product) 3rd ed. New Delhi: National Institute of Science
Communication and Council of Industrial and Scientific Research; 2002. Anonymous.

Haque R, Ali M.S., Saha A, Allimuzzaman M., 2006. Analgesic activity of methanolic extract of the leaf of Erythrina variegata. J Pharm Sci., 5, 77-79.

Harborne JB Phytochemical methods. Chapman and Hall Ltd., London. 1973, 49-188.

Idowu, Y.O. Onawunmi, G.O.Ogundani, A.O. Adesanya, S.A. 2003. Antimicrobial constituents of Crysophyllum albidum seed: Cotyledon. Nigerian Journal of veterinary production and medicine., 7:33-36.

Murray PR, Rosenthal KS, Pfaller MA (2009). Medical microbiology: Mosby Inc.

Muthukrishnana S., Palanisamy S., Santhanam I., Kaveriyappan G., 2014. Phytochemical Screening and Antimicrobial Activity of Erythrina Variegata, Dept of Biochemistry, Periyar University, Salem 11, Tamil Nadu, India, Vol 3, Issue 6, 680-690.

Srinivasan, D., Nathan, S., Suresh, T., Perumalsamy, O., 2001.Antimicrobial activity of certain Indian medicinal plants used in folkloric medicine. Journal of Ethnopharmacology., 74, 217-220.

Viji M, Murugesan S., 2010. Phytochemical analysis and antibacterial activity of medicinal plant Cardiospermum halicacabum Linn. Pytopharmacol., 2: 68-77.

Warrier P.K, Nambiar V.P, Ramankutty C. editors. Indian medicinal plants a compendium of 500 species. 1st ed. Hyderabad: Orient Longman Limited; 1994. Anonymous; p. 1994.

\section{How to cite this article:}

Preeti Kumari, Subhankar K. Singh and Chandrawati Kumari. 2017. Phytochemical Screening and Antibacterial Activity of Erythrina variegata L. (Leaf Extract). Int.J.Curr.Microbiol.App.Sci. 6(6): 2500-2505. doi: https://doi.org/10.20546/ijcmas.2017.606.297 